\title{
ПОЛУЧЕНИЕ НОВОЙ ЛЕКАРСТВЕННОЙ ФОРМЫ ПРОИЗВОДНЫХ НЕНАСЫЩЕННЫХ ЖИРНЫХ КИСЛОТ В ВИДЕ ПОЛИМЕРНЫХ НАНОЧАСТИЦ ДЛЯ АНТИБАКТЕРИАЛЬНОЙ ТЕРАПИИ
}

\author{
Е.Д. Никольская', В.А. Сохранева, ${ }^{1,2}$, Н.В. Гроза², Н.Э. Грамматикова \\ Н.Г. Яббаров ${ }^{1}$, М.Б. Сокол', М.Р. Моллаева', М.В. Фомичева' \\ ${ }^{1}$ Институт биохимической физики им. Н.М. Эмануэля РАН, \\ 119334, Россия, г. Москва, ул. Косыгина, д. 4. \\ 2МИРЭА - Российский технологический университет, \\ 119454, Россия, г. Москва, пр. Вернадского, д. 78. \\ ${ }^{3}$ ФББУ Научно-исследовательский институт по изысканию новых антибиотиков \\ им. Г.Ф. Гаузе, 119021, Россия, г. Москва, ул. Большая Пироговская, д. 11, стр. 1.
}

DOI: 10.19163/MedChemRussia2021-2021-199

E-mail: elenanikolskaja@gmail.com

Перспективным направлением при создании пролекарств является разработка препаратов на основе природных соединений. Механизмы антибактериального действия фенольных соединений и ненасыщенных жирных кислот (НЖК) обусловлены изменением проницаемости клеточных мембран и различных внутриклеточных функций, вызванных связыванием водорода фенольных соединений с ферментами, или модификацией жесткости клеточной стенки. Применение антибиотиков ограничено их низкой биодоступностью. Наночастицы из сополимера молочной и гликолевой кислот (PLGA) в качестве систем доставки препаратов позволяют сохранять стабильность включенных препаратов, увеличивать их биодоступность, а также уменьшать неспецифическую токсичность благодаря пассивной доставке таких систем.

Были синтезированы конъюгаты производных фенола и НЖК: ЭТОК 2-изопропил-5-метилфенилолеат и ТЛК - 2-изопропил-5-метилфениллинолеат, которые затем были инкапсулированы в наночастицы PLGA с помощью метода одинарных эмульсий. Полученные частицы обладали средним диаметром не более 250 нм, дзета-потенциалом -15мВ, степенью включения 65\% и общим содержанием действующего вещества около $13 \%$.

В экспериментах in vitro было показано, что субстанции ТЛК и ЭТОК не проявили активности ни к одному из тест-штаммов (МПК больше 5000 мкг/мл), что может быть обусловлено их низкой биодоступностью в связи с ограниченной растворимостью в водных средах. При этом наночастицы обладали высоким уровнем антибактериальной активности: НЧ-ТЛК в отношении S.aureus ATCC 29213, B.cereus ATCC 10702; НЧ-ЭТОК в отношении Candida albicans ATCC 10231 и Aspergillus niger 37a, превосходя по активности тимол в 2-4 раза.

Таким образом, было показано увеличение биодоступности и антибактериальной активности субстанций после включения их в наночастицы - новую лекарственную форму. 